\title{
"I felt what was happening in our country [USA] with race was so much scarier than the [COVID-19] virus." Black Lives Matter protesters' beliefs and practices during the COVID-19 pandemic
}

\section{Evelyn Arana-Chicas ( $\sim$ Evelyn_Arana@urmc.rochester.edu )}

University of Rochester School of Medicine and Dentistry https://orcid.org/0000-0001-8666-6468

Brooke D Jones

Xavier University of Louisiana

Francisco Cartujano-Barrera

University of Rochester School of Medicine and Dentistry

Ana Paula Cupertino

University of Rochester School of Medicine and Dentistry

Research

Keywords: Social justice, COVID-19 guidelines, protesting, black lives matter

Posted Date: September 8th, 2020

DOl: https://doi.org/10.21203/rs.3.rs-68862/v1

License: (c) (i) This work is licensed under a Creative Commons Attribution 4.0 International License.

Read Full License

Version of Record: A version of this preprint was published at Journal of Health Ethics on January 1st, 2021. See the published version at https://doi.org/10.18785/jhe.1701.02. 


\section{Abstract}

Background: The killing of George Floyd triggered the Black Lives Matter protests against police brutality and social injustices in the midst of the COVID-19 pandemic. No research to date has assessed the COVID-19 prevention practices and beliefs of protesters. The purpose of this study was to assess COVID19 prevention practices and beliefs of Black Lives Matter protesters in the USA.

Methods: A pilot mixed methods study was employed. Participants completed a survey collecting data on their frequency in following COVID-19 recommended guidelines and answered open-ended interview questions to elucidate the results from the survey.

Results: Twenty participants completed the study. Participants' average age was 29 and most participants were female (80\%) and black (75\%). Most always or almost always properly wore their masks (50\% and $25 \%$, respectively) and washed their hands during a protest 2-3 times or more than 3 times (35\% and 50\%, respectively). Although all believed that COVID-19 testing is important (90\%), most had never been tested (85\%) and most did not self-quarantine for 14 days after protesting (95\%). Moreover, most participants reported never or rarely following social distancing guidelines at a protest (25\% and $30 \%$, respectively) and most reported being Not at all or Slightly concerned about COVID-19 while at a protest ( $25 \%$ and $30 \%$, respectively). Qualitative data highlighted the following themes: 1 ) Fighting for social justice, 2) Protesting being more important than COVID-19, 3) Unable to keep $6 \mathrm{ft}$ distance, 4) Masks worn most of the time, 5) Protests sparked global movement, and 6) Increasing awareness of injustices.

Conclusion: Although protesters believe that both the fight for social justice and taking precautions during the COVID-19 pandemic are important, they believe the fight for social justice is more important than the COVID-19 pandemic. However, they understand the importance of COVID-19 and try to practice the recommended guidelines to prevent its spread while protesting. These results make an important contribution for policies for controlling the spread of the disease, and also understanding human behavior of protesting for social justice during a pandemic.

\section{Introduction}

The novel coronavirus, SARS-CoV-2, was first detected in December 2019, in Wuhan, China. It has rapidly spread throughout the globe, prompting the World Health Organization ${ }^{1}$ (WHO) to declare a pandemic on March 11, 2020. SARS-CoV-2 can result in severe respiratory infection, causing coronavirus disease (COVID-19). As of August 26, 2020, in the U.S., COVID-19 has infected over 5.5 million Americans and resulted in over 170,000 deaths. ${ }^{2}$ Chronic illness, older age, smoking and obesity have been identified as vulnerabilities for more severe COVID-19 outcomes. ${ }^{3}$ To combat this novel coronavirus, governments have recommended frequent hand washing, wearing masks in public spaces, and keeping 6 feet distance from others. ${ }^{4}$ 
For years, racism in the U.S. has been a deeply entrenched public health issue resulting in numerous health disparities, ${ }^{5}$ including racial and ethnic minorities being more likely to suffer from chronic illness, die from cancer, and die during childbirth compare to their white counterparts. These long-standing systemic health and social inequities have placed racial and ethnic minorities at increased risk of getting sick and dying from COVID-19. Racial and ethnic minorities have an increased burden of comorbidities, are more likely to work closely with the public, and are more likely to reside in crowded dwellings ${ }^{6}$ - all conditions that propagate the spread of, and worsen the prognosis of, COVID-19. In fact, studies have shown that racial and ethnic minorities are much more likely to get infected and die from COVID-19 compared to whites. ${ }^{7,8}$

Research also shows that racial and ethnic minorities are significantly more likely than whites to be killed by a police officer. ${ }^{9}$ Risk is highest for black men, who face about a 1 in 1,000 chance of being killed by police comapred to 39 per 100,000 for white men over the life course. The killing of George Floyd, ${ }^{10} \mathrm{a}$ Black male, on May 25, 2020 triggered Black Lives Matter (BLM) protests ${ }^{11}$ against police brutality and social injustices in the midst of the COVID-19 pandemic. An estimated 15 million to 26 million have taken

to the streets to partake in these protests, ${ }^{12}$ with representation of all racial and ethnic groups. ${ }^{13}$ Many of them were protesting for the first time, recognizing and acknowledging racism. ${ }^{14,15}$

Numerous protests have and continue to occurr in spite of the COVID-19 pandemic. Public health officials have warned that mass protests could lead to a reduction in social distancing behavior and cause a spike of COVID-19. ${ }^{16,17}$ Because of this, it is important to collect data on protesters' prevention practices and beliefs while protesting during the COVID-19 pandemic. The purpose of this study is to assess the COVID19 prevention practice and beliefs of individuals protesting during the COVID-19 pandemic. This data may make an important contribution for policies for controlling the spread of the disease, and also understanding human behavior of protesting for social justice during a pandemic.

\section{Methods}

\section{Study Design}

A pilot mixed methods study was employed. ${ }^{18}$ The survey and qualitative questions drew on principles from the Stress and Coping Theory, ${ }^{19}$ which posits that coping involves behavioral responses one uses to manage stressors, and the Social Movement Theory, ${ }^{20}$ which seeks to explain why social mobilization occurs and potential social and political consequences. The study was approved and monitored by the University of Rochester IRB committee.

\section{Sampling and Recruitment}

Participants were recruited using reactive convenience sampling from a post in the JustUs4 Facebook group, a group based in St. Louis, MO that organizes Black Lives Matter protests. A recruitment announcement was posted in this group on July 13, 2020 calling for interested individuals to participate in this study. Interested participants messaged the JustUs4 organization directly via Facebook to assess 
eligibility and, if eligible, to schedule time for the assessment. From July 15 to July 21, 2020, 20 participants were recruited into this study.

Eligibility included 1) being 18 years or older, 2) speaking English, and 3) having attended at least one protest. Verbal informed consent was obtained from each participant. All participants received a \$20 gift card.

\section{Measures}

Quantitative phase. Participants enrolled in the study participated in an interviewer-administered survey that included questions on demographics and prevention practices and behaviors while protesting. For example, participants were asked Likert-style questions such as 'How often did you properly wear your face mask while protesting (this involves wearing a face mask over your mouth, nose, and chin)?' and 'How often were you able to practice social distancing while protesting (keeping at least 6 feet apart from others)?'The survey took approximately 10 minutes to complete and was administered via Zoom.

Qualitative phase. Immediately upon completion of the quantitative survey, all participants were asked questions to elucidate their quantitative responses. This phase included open-ended questions such as 'You mentioned you were able to keep your distance (their frequency) during protests. Please explain why.' and 'In your perspective, what has been the impact of the protests?' This interview took approximately 15 minutes to complete and was audio recorded and administered via Zoom.

\section{Analysis}

Frequencies, means, and standard deviations were calculated for all variables using Microsoft Excel. Interviews were transcribed and coded by the first and second author using deductive and inductive thematic analysis. ${ }^{21}$ An iterative process was employed to achieve consensus between the two sets of codes, resulting in a codebook that included agreed-upon definitions. ${ }^{22}$

\section{Results}

Twenty participants completed this study. Their mean age was 29 (SD 12.5, range 19-59). Most were female (80\%), heterosexual (70\%), had a high school diploma (65\%), and had health insurance $(85 \%)$. The majority identified as Black/African American (75\%) and have never been married (70\%). Half of the participants reported being in 'Good' health, while 40\% reported having one morbidity present. 
Table 1

Subject Characteristics $(\mathrm{n}=20)$

\begin{tabular}{|ll|}
\hline Variable & $\mathbf{n}(\%)$ \\
\hline Age, mean (SD, range) & $29(12.5$, range 19-59) \\
\hline Ethnicity, Non-Hispanic Latino & $19(95 \%)$ \\
\hline Race & $1(5 \%)$ \\
American Indian & $15(75 \%)$ \\
Black/African American & $3(15 \%)$ \\
White & $1(5 \%)$ \\
Multiracial & \\
\hline Sex - Female & $16(80 \%)$ \\
\hline Sexual Orientation & $14(70 \%)$ \\
Heterosexual & $4(20 \%)$ \\
Bisexual & $1(5 \%)$ \\
Not Sure & $1(5 \%)$ \\
Refused & $14(70 \%)$ \\
\hline Education Level & $7(35 \%)$ \\
More than High School & $13(65 \%)$ \\
High School Graduate & \\
\hline Marital Status & $4(20 \%)$ \\
Divorced/Separated & $2(10 \%)$ \\
Married/Cohabitating & $10(50 \%)$ \\
Never Been Married & $4(20 \%)$ \\
\hline Annual Income & $1(5 \%)$ \\
\$10,000 - \$59,000 & \\
\$60,000 + & \\
Not Sure & $14 \%)$ \\
\hline Refused & \\
\hline
\end{tabular}




\begin{tabular}{|ll|}
\hline Variable & $\mathbf{n}(\%)$ \\
\hline Health Status & $4(20 \%)$ \\
Excellent & $6(30 \%)$ \\
Very Good & $10(50 \%)$ \\
Good & $17(85 \%)$ \\
Health Insurance & \\
Yes & $8(40 \%)$ \\
\hline Morbidity Present & \\
Yes & \\
* These participants have depression $(n=5)$, hypertension \\
(n=1), or chronic lung disease $(n=2)$
\end{tabular}

Table 2 shows participants' protest practices and beliefs during the COVID-19 pandemic. On average, participants attended 3.8 protests and spent an average of 3.7 hours at a single protest. The latest dates participants' protested ranged from June 1 to July 14, 2020. Participants reported that attendance at the smallest protest they attended was on average 149 individuals while the largest protest they attended reached an average of 4,137 individuals. Most participants attended a protest without having COVID-19 symptoms (95\%), always or almost always properly wore their masks ( $50 \%$ and $25 \%$, respectively), and washed their hands during a protest $2-3$ times or more than 3 times (35\% and $50 \%$, respectively). Almost all participants believe that COVID-19 testing is important (90\%). However, most have never been tested for COVID-19 (85\%) and most did not self-quarantine for 14 days after protesting (95\%). Moreover, most participants reported never or rarely following social distancing guidelines at a protest $(25 \%$ and $30 \%$, respectively). When asked whether other protesters around them at a protest followed these COVID-19 guidelines, similar results were obtained (Table 2). Most participants reported being Not at all or Slightly concerned about COVID-19 while at a protest ( $25 \%$ and $30 \%$, respectively). The majority of participants believe that protesting is extremely important $(70 \%)$. 
COVID-19 prevention practices and beliefs while protesting $(n=20)$

$\mathrm{n}(\%)$

Average \# of protests attended, mean (SD range,)

$3.8(2.9$, range $1-10)$

Average \# of people in largest and smallest protests attended, mean, $149(236.6$, range $45-1,000)$ (SD, range)

Smallest $4,137(2673.3$, range $500-$ $10,000)$

Largest

Average Hours in 1 protest, mean (SD, range)

$3.7(1.5$, range $1.5-7)$

Ever tested for COVID-19

$17(85 \%)$

No

$3(15 \%)$

Yes, Viral Test ${ }^{*}$

Believe COVID-19 testing is important $18(90 \%)$

Yes

Attended protests while having COVID-19 symptoms

$19(95 \%)$

No

$1(5 \%)$

Yes (cough)

\section{Proper Mask Wearing}

$5(25 \%)$

Sometimes

$5(25 \%)$

Always

$10(50 \%)$

Almost Always

\section{Proper Social Distancing}

$5(25 \%)$

Never

$6(30 \%)$

Rarely

$4(20 \%)$

Sometimes

$4(20 \%)$

Almost Always

$1(5 \%)$

Always 


\begin{tabular}{|c|c|}
\hline & $\mathrm{n}(\%)$ \\
\hline Other Protesters Wearing Masks Properly & $1(5 \%)$ \\
\hline Rarely & $3(15 \%)$ \\
\hline Sometimes & $11(55 \%)$ \\
\hline Almost Always & $5(25 \%)$ \\
\hline \multicolumn{2}{|l|}{ Always } \\
\hline Other Protesters Practicing Social Distancing & $5(25 \%)$ \\
\hline Never & $6(30 \%)$ \\
\hline Rarely & $5(25 \%)$ \\
\hline Sometimes & $4(20 \%)$ \\
\hline \multicolumn{2}{|l|}{ Almost Always } \\
\hline Times Washed Hands at Protests & $2(10 \%)$ \\
\hline Never & $1(5 \%)$ \\
\hline Once & $7(35 \%)$ \\
\hline $2-3$ times & $10(50 \%)$ \\
\hline \multicolumn{2}{|l|}{ More than 3 times } \\
\hline Concern for COVID-19 & $5(25 \%)$ \\
\hline Not at all concerned & $6(30 \%)$ \\
\hline Slightly concerned & $3(15 \%)$ \\
\hline Somewhat concerned & $5(25 \%)$ \\
\hline Moderately concerned & $1(5 \%)$ \\
\hline \multicolumn{2}{|l|}{ Extremely Concerned } \\
\hline Importance of Protesting & $3(15 \%)$ \\
\hline Somewhat Important & $3(15 \%)$ \\
\hline Moderately Important & $14(70 \%)$ \\
\hline \multicolumn{2}{|l|}{ Extremely Important } \\
\hline Self-quarantined for 14 days after protest & $19(95 \%)$ \\
\hline No & \\
\hline
\end{tabular}


Table 3 shows the themes and select quotes that were identified when analyzing the qualitative data, which included 1) Fighting for social justice (e.g., "I protest because I'm tired of police brutality", 2) Protesting is more important than COVID-19 (e.g., "I was more concerned about organizing the protest. I was thinking about the Black Lives Matter movement a lot more than the pandemic"), 3) Unable to keep 6 $\mathrm{ft}$ distance (e.g., "You gotta keep up with leaders/organizers to hear what they say and chant. Everyone forgets about distancing"), 4) Masks worn most of the time (e.g., "I was chanting a lot. When not chanting, I tried to keep my mask up"), 5) Protests sparked global movement (e.g., "I think they [protests] brought attention because they haven't been in one specific city but all over the county and the world. It's united people"), and 6) Increasing awareness of injustices (e.g., "It's been bringing awareness to a lot of people. It's been pressuring our local officials to make change"). Saturation of themes was reached. ${ }^{22}$ 
Table 3

Themes and quotes from participants regarding COVID-19 prevention practices and beliefs while protesting $(n=20)$.

\section{Theme Select quotes from participants}

Fighting "George Floyd happened and that hit me. I couldn't ignore what was going on. I wanted for social to help other people." - Male, 19 years old

justice

"My people are getting killed every day whether it's getting caught on camera or not. Our voices are finally being heard so why not go out there and try to make a change." -

Female, 21 years old

"I protest because I'm tired of police brutality and tired of people killing black people." Female, 30 years old

Protesting is more important than COVID-19
"I personally felt what was happening in our country with race was so much scarier than the virus." - Female, 31 years old

"I was more concerned about organizing the protest. I was thinking about the Black Lives Matters movement a lot more than the pandemic." - Female, 21 years old

"I think the cause to protest was greater than me thinking about COVID-19. Would I do it again? Yes." - Female, 49 years old

Unable to keep $6 \mathrm{ft}$ distance

"You gotta keep up with leaders/organizers to hear what they say and chant. Everyone forgets about distancing." - Male, 19 years old
“Sometimes there was just so many people that when we were marching there wasn't room to be 6 feet. It was more like 3 feet." - female, 52 years old

"It's important to look at also the state and police and their role exacerbating the pandemic issues for protesters. When the government and police work together to militarize and commit violence against protesters, then it makes it harder for protesters to maintain distance practices." - Female, 52 years old

Masks worn most of the time

"We did our best to wear masks and sanitize our hands. We tried our best to not spread the virus while still protesting and trying to make a difference." - Female, 20 years old

"I was chanting a lot. When not chanting, I tried to keep my mask up." - Female, 21 years old

"I kept my face mask on aside from drinking water." - Female, 49 years old

Protests sparked global movement
"There is nationwide and worldwide response and support. People are recognizing there is a problem happening. The world has woken up." - Female, 20 years old

"There are BLM protests in other countries that have far smaller population of black people that haven't had same history of oppression as USA has. It's a global movement."- Female, 52 years old

"I think they [protests] brought attention because they haven't been in one specific city but all over the county and the world. It's united people." - Female, 28 years old 


\section{Theme Select quotes from participants}

Increasing

awareness

of

injustices
"BLM is getting more powerful and making sure people are aware of social injustices and puts pressure on systems oppressing minorities." - Female, 21 years old

"It's been bringing awareness to a lot of people. It's been pressuring our local officials to make change." Male, 19 years old

"So many people have been coming out and giving support and people who I haven't thought were for the BLM are coming aboard and have a better understanding of why we're protesting. We're changing people's opinions and lawmakers are listening."

\section{Discussion}

This study reports on COVID-19 prevention practices and beliefs of individuals protesting during the COVID-19 pandemic. Although protesters believe the fight for social justice is more important than the COVID-19 pandemic, they understand the importance of COVID-19 and try to practice the recommended guidelines to prevent the spread of the virus. Nevertheless, participants reported taking off their masks when chanting, which can exacerbate the spread of respiratory droplets. ${ }^{23}$

As reported by one participant, it is important to consider the role that law enforcement plays in exacerbating the virus. Law enforcement maneuvers such as tear gas and mace trigger coughing and watering of the eyes, increasing the likelihood of spreading the virus. ${ }^{24}$ Tear gas and pepper spray may cause others to help those who received the tear gas, putting them in close proximity with someone who may potentially have the virus. Furthermore, a 2014 study from the U.S. Army found that being exposed to tear gas increases one's likelihood of becoming sick with respiratory illnesses, such as the cold or flu. ${ }^{25}$ COVID-19 could therefore be exacerbated by using such tactics. Government officials should issue a freeze on the use of these measures during a global pandemic.

A nationwide study of protests in 315 U.S. cities estimated the impacts of mass protests on social distancing, COVID-19 incidence increases, and COVID-19 mortality rates. ${ }^{26}$ They reported that protests have inadvertently caused an increase in social distancing behavior from individuals not participating in protests who chose to avoid public places, thereby having an offsetting effect in spreading COVID-19. In fact, their study found no evidence that protests reignited COVID-19 cases or deaths after more than five weeks following the onset of protests. Although these protests are not criminal activities, this type of avoidance behavior is consistent with the literature on crime, violence, and safety amongst the general population, ${ }^{27,28}$ who choose to remain home more often. It is possible that in our study, this same avoidance behavior was observed among non-protesters, leveling out any potential increase in COVID-19 cases.

In this study, most participants have never been tested for COVID-19 despite recognizing the importance of testing. The CDC currently only advises people to get tested if they have COVID-19 symptoms, if they 
had close contact with someone positive for COVID-19, or if they have been asked by a health care provider. ${ }^{29}$ It is possible that participants not only did not meet this criteria, but also may not have had easy access to a COVID-19 test. However, this was not assessed in the study. Given the relatively young age of participants in this study, if infected with COVID-19, they may have had less severe symptoms, or no symptoms at all, ${ }^{30}$ and thus may also explain why they never got tested. Moreover, young adults have been shown to be less likely to social distance, as supported by this study where most participants did not self-quarantine after protesting, possible because they overrate their own control over whether they get sick or they take social cues from peers. ${ }^{31}$ Public health campaigns with young adults showcasing the importance of social distancing can be useful to target this behavior. It is important to note that all but one participant was asymptomatic while protesting. However, it takes just one person to spread the virus among others. ${ }^{32}$ It would be helpful for future studies to assess if participants have selfquarantined prior to attending a protest as they can help clarify whether they were truly asymptomatic while protesting. ${ }^{33}$

Despite COVID-19 concerns, protesters felt compelled to participate in protests and have their voices heard. This study's results make an important contribution to the current discussion around policies for controlling the spread of COVID-19, and also to the understanding of human behavior of protesting for social justice during a pandemic.

\section{Limitations and Strengths}

This study has several important limitations that affect the generalizability of the results. The small sample size and convenience sample may differ from the general population of protesters. Furthermore, there may be volunteer bias, where participants in this study may be different from those who chose not

to volunteer. ${ }^{34}$ All data collected were self-reported; thus, there is a potential for over- or under-reporting as participants may have felt compelled to offer socially desirable responses. ${ }^{35}$ This study also has a sampling bias with our sample being predominantly female (80\%), limiting generalizability with respect to male protesters. Moreover, protesting behaviors may be different in St. Louis, MO, an urban city with a much lower population per square mile ${ }^{36}$ (5,157.5 people per square mile) compared to other denser urban cities such as New York City ${ }^{37}$ (27,012.5 people per square mile). Despite these limitations, this study also has strengths. This is the first study to assess COVID-19 preventive practices and beliefs among protesters. The collection of qualitative data also strengthened and supported the quantitative portion of this study.

\section{Conclusion}

This study assessed the COVID-19 prevention practices and beliefs of protesters. Twenty participants completed the study. Results illustrate that overall, protesters understand the importance of COVID-19 and try to practice the recommended guidelines to prevent the spread of COVID-19. Qualitative data highlight themes that arose, including 1) Fighting for social justice, 2) Protesting is more important than 
COVID-19, 3) Unable to keep $6 \mathrm{ft}$ distance, 4) Masks worn most of the time, 5) Protests sparked global movement, and 6) Increasing awareness of injustices. Results may contribute to the formulation of policies for controlling the spread of COVID-19 and in understanding human behavior of protesting for social justice during a pandemic.

\section{Declarations}

Ethica approval and consent to participate. This study was approved by the University of Rochester IRB. All participants provided verbal consent to participate.

Availability of data. The data that support the findings of this study are available on reasonable request. Consent for publication. Not applicable.

Competing interests. The authors declare that they have no competing interests.

Funding. This research was funded by the Community Outreach \& Engagement Office at The University of Rochester School of Medicine \& Dentistry.

\section{Authors' contributions.}

Evelyn Arana-Chicas. Made substantial contributions to the conception, design,of the work, analysis and manuscript draft, has approved the submitted version, and has agreed to be personally accountable for the author's own contributions and to ensure that questions related to the accuracy or integrity of any part of the work, even ones in which the author was not personally involved, are appropriately investigated, resolved, and the resolution documented in the literature.

Brooke D. Jones. Made substantial contributions to the conception, acquisition of data and analysis of the data, has approved the submitted version, and has agreed to be personally accountable for the author's own contributions and to ensure that questions related to the accuracy or integrity of any part of the work, even ones in which the author was not personally involved, are appropriately investigated, resolved, and the resolution documented in the literature.

Francisco Cartujano-Barrera. Made substantial contribution to the design of the work and has substantially revised the work, has approved the submitted version, and has agreed to be personally accountable for the author's own contributions and to ensure that questions related to the accuracy or integrity of any part of the work, even ones in which the author was not personally involved, are appropriately investigated, resolved, and the resolution documented in the literature.

Paula Cupertino. Made substantial contributions to the conception, design of the work, and substantially revised it, has approved the submitted version, and has agreed to be personally accountable for the author's own contributions and to ensure that questions related to the accuracy or integrity of any part of 
the work, even ones in which the author was not personally involved, are appropriately investigated, resolved, and the resolution documented in the literature.

Acknowledgements. This study was supported by the help of Veronica Ginani, who helped us with the IRB submission for this study. This study was part of a research project of co-author Brooke D. Jones, while a fellow with the Summer Undergraduate Research Fellow (SURF) summer program at the University of Rochester School of Medicine and Dentistry in 2020.

\section{References}

1. WHO Director-General's opening remarks at the media briefing on COVID-19 - 11 March 2020. World Health Organization. 2020. Mar 11, [2020-04-29]. https://www.who.int/dg/speeches/detail/whodirector-general-s-opening-remarks-at-the-media-briefing-on-covid-19-11-march-2020. Accessed 25 August 2020.

2. Center for Disease Control and Prevention. Coronavirus Disease 2019 (COVID-19) - Cases and Deaths in the U.S. Available from https://www.cdc.gov/coronavirus/2019-ncov/cases-updates/uscases-deaths.html. Accessed 25 August 2020

3. Garg S, Kim L, Whitaker M, et al. Hospitalization rates and characteristics of patients hospitalized with laboratory-confirmed coronavirus disease 2019-COVID-NET, 14 United States, March 1-30, 2020. MMWR Morb Mortal Wkly Rep. 2020;69(15):458-464.

4. Center for Disease Control and Prevention. Coronavirus Disease 2019 (COVID-19) - How to Protect Yourself and Others. Available from https://www.cdc.gov/coronavirus/2019-ncov/prevent-gettingsick/prevention.html. Accessed 25 August 2020.

5. Gee GC, Ford CL. Structural Racism and Health Inequities. Du Bois Review. 2011;8:115-132.

6. Hooper MW, Napoles AM, Perez-Stable E. COVID-19 and Racial/Ethnic Disparities. JAMA. 2020; doi:10.1001/jama.2020.8598.

7. Cyrus E, Clarke R, Hadley D, Bursac Z, Trepka MJ, Dévieux JG, Bagci U, Furr-Holden D, Coudray M, Mariano Y, Kiplagat S, Noel I, Ravelo GJ, Paley M, Wagner E. The Impact of COVID-19 on African American Communities in the United States. MedRxiv. 2020; doi: 10.1101/2020.05.15.20096552.

8. Miller GA, Jones AT, Benkeser D, Baral S, Mercer L, Beyrer C, Honermann B, Lankiewicz E, Mena L, Crowley JS, Sherwood J, Sullivan PS. Assessing differential impacts of COVID-19 on black communities. 2020; doi.org/10.1016/j.annepidem.2020.05.003.

9. Edwards F, Lee H, Esposito M. Risk of being killed by police use of force in the United States by age, race-ethnicity, and sex. 2019; doi: 10.1073/pnas.1821204116.

10. Hill, Evan, Ainara Tiefenthäler, Christiaan Triebert, Drew Jordan, Haley Willis and Robin Stein. (2020, May 31). "8 Minutes and 46 Seconds Became a Symbol in George Floyd's Death. The exact time is less clear." The New York Times. Available from https://www.nytimes.com/2020/06/18/us/georgefloyd-timing.html. Accessed 25 August 2020. 
11. Taylor, Derrick Bryson. (2020, June 9) "George Floyd Protests: A Timeline" The New York Times. Available from https://www.nytimes.com/article/george-floyd-protests-timeline.html. Accessed 25 August 2020.

12. Arora M. How the coronavirus pandemic helped the Floyd protests become the biggest in U.S. history. The Washington Post. 2020. Available from https://www.washingtonpost.com/politics/2020/08/05/how-coronavirus-pandemic-helpedfloyd-protests-become-biggest-us-history/. Accessed 25 August 2020.

13. Fisher DR. The diversity of the recent Black Lives Matter protests is a good sign for racial equity. Brookings. 2020. Available from https://www.brookings.edu/blog/how-we-rise/2020/07/08/thediversity-of-the-recent-black-lives-matter-protests-is-a-good-sign-for-racial-equity/. Accessed 26 August 2020

14. Gibson AN, Chancellor R, Cooke NA, Dahlen SP, Patin B. Struggling to Breathe: COVID-19, Protest, and the LIS response. Equality, Diversity, and Inclusion. 2020; doi.org/10.1108/EDI-07-2020-0178.

15. Buchanan L, Bui Q, Patel JK. Black Lives Matter May Be the Largest Movement in U.S. History. The New York Times. 2020. Available from https://www.nytimes.com/interactive/2020/07/03/us/george-floyd-protests-crowd-size.html. Accessed 26 August 2020.

16. Harmon A, Rojas R. A Delicate Balance: Weighing Protest Against the Risks of the Coronavirus. The New York Times. 2020. Available from https://www.nytimes.com/2020/06/07/us/Protestcoronavirus-george-floyd.html. Accessed 26 August 2020

17. Bacon J. Coronavirus updates: George Floyd protests could fuel COVID cases, USA Today. 2020. Available from https://www.usatoday.com/story/news/health/2020/05/31/coronavirus-updatedonald-trump-g-7-summit-church-reopenings-cuomo/5293061002/. Accessed 26 August 2020.

18. Maxwell JA. Qualitative Research Design. 3rd ed. Los Angeles: Sage; 2013.

19. Lazarus R. Stress, appraisal, and coping. New York: Springer; 1984.

20. Morris A, Mueller CM. Frontiers in social movement theory. New Haven: Yale University Press. 1992.

21. Joffe H, Yardley L. Research Methods for Clinical and Health Psychology. London, UK: Sage Publications; 2004.

22. Ando H, Cousins R, Young C. Achieving Saturation in Thematic Analysis: Development and Refinement of a Codebook. Comprehensive Psychology. 2014; doi:10.2466/03.CP.3.4.

23. Wei J., Li Y. Airborne spread of infectious agents in the indoor environment. American Journal of Infection Control. 2016;44:S102-S108.

24. Khullar D. How the protests have changed the pandemic. The New Yorker. 2020 Available from https://www.newyorker.com/science/medical-dispatch/how-the-protests-have-changed-thepandemic. Accessed 26 August 2020.

25. Hout JJ, White DW, Artino AR, Knapik JJ. O-chlorobenzylidene malononitrile (CS riot control agent) associated acute respiratory illnesses in a U.S. Army Basic Combat Training cohort. Observational Study. 2014; doi: 10.7205/MILMED-D-13-00514. 
26. Dave DM, Friedson Al, Matsuzawa K, Sabia JJ, Safford S. Black Lives Matter Protests, Social Distancing, and COVID-19. National Bureau of Economic Research. 2020; Available from https://www.nber.org/papers/w27408. Accessed 26 August 2020.

27. Bennett GG, McNeil LH, Wolin KY, Duncan DT, Puleo E, Emmons KM. Safe to walk? Neighborhood safety and physical activity among public housing residents. PLoS medicine, 2007;4.

28. Stolzenberg L, D'Alessio SJ and Flexon JL. The Impact of Violent Crime on Obesity. Social Sciences. 2019; 8:329.

29. Centers for Disease Control and Prevention. Testing for COVID-19. 2020. Available from https://www.cdc.gov/coronavirus/2019-ncov/symptoms-testing/testing.html. Accessed 26 August 2020.

30. Liao J, Fan S, Chen J, Wu J, Xu S, Guo Y, Li C, Zhang X, Wu C, Mou H, Song C, Wu G, Zhang J, Guo L, Lui H, Lv J, Xu L, Lang C. Epidemiological and Clinical Characteristics of COVID-19 in Adolescents and Young Adults. The Innovation. 2020; https://doi.org/10.1016/j.xinn.2020.04.001.

31. Pinsker J. The People Ignoring Social Distancing. The Atlantic. 2020. Available from https://www.theatlantic.com/family/archive/2020/03/coronavirus-social-distancingsocializing-bars-restaurants/608164/. Accessed 26 August 2020.

32. Shereen MA, Khan S, Kazmi A, Bashir N, Siddique R., COVID-19 infection: Origin, transmission, and characteristics of human coronaviruses. Journal of Advanced Research. 2020; 24: doi.org/10.1016/j.jare.2020.03.005.

33. Ali M, Shah ST, Imran M, Khan A. The role of asymptomatic class, quarantine and isolation in the transmission of COVID-19. Journal of Biological Dynamics. 2020;14:

DOI:10.1080/17513758.2020.1773000.

34. Dodge HH, Katsumata Y, Zhu J, Mattek N, Bowman M, Gregor M, Wild K, Kaye JA. Characteristics associated with willingness to participate in a randomized controlled behavioral clinical trial using home-based personal computers and a webcam. BMC. 2014;508: doi.org/10.1186/1745-6215-15508.

35. Fisher RJ. Social Desirability Bias and the Validity of Indirect Questioning. Journal of Consumer Research. 1993;20:303-315.

36. United States Census Bureau. QuickFacts: St. Luis city, Missouri. Available from https://www.census.gov/quickfacts/stlouiscitymissouricounty. Accessed 26 August 2020.

37. United States Census Bureau. QuickFacts: New York city, New York. Available from https://www.census.gov/quickfacts/newyorkcitynewyork?. Accessed 26 August 2020. 